\title{
Effect of Plastic Mulch Type and Insecticide on Incidence of Tomato Spotted Wilt, Plant Growth, and Yield of Tomato
}

\author{
Peter C. Andersen"1, Stephen M. Olson, and M. Timur Momol \\ University of Florida North Florida Research and Education Center, 155 \\ Research Road, Quincy, FL 32351
}

\section{Joshua H. Freeman \\ Virginia Tech University, Eastern Shore Agricultural Research and Education Center, 33446 Research Drive, Painter, VA 23420}

Additional index words. Bunyaviridae, Solanum lycopersicon, thrips, TSW, TSWV, Tospovirus

\begin{abstract}
Tomato spotted wilt (TSW) is caused by a Tospovirus [tomato spotted wilt virus (TSVW)] and is vectored by thrips. TSW is a major impediment to tomato production worldwide and has been identified as the most significant limitation in the southeastern United States. The objectives of this study were to quantify the impact of polyethylene mulch type (black, metalized, Heat stripe, and Sonoco printed) and insecticide (alternating applications of spinosad and methamidophos) on midafternoon soil temperature under the mulch, reflected photosynthetic photon flux $(P P F)$, vegetative growth, flower number, incidence of TSW, yield, and fruit quality of 'FL-47' tomato (Solanum lycopersicum L.). Midafternoon soil temperature during April and May (10-cm depth) averaged 2 to $4{ }^{\circ} \mathrm{C}$ higher under black mulch compared with the other mulches. The reflectance of $P P F$ was highest for metalized mulch (up to two-thirds of $P P F$ in full sunlight) followed by Heat stripe, Sonoco printed, and black mulch. In the presence of a full plant canopy, $P P F$ reflectance was greatly reduced. The incidence of TSW [as determined visually and confirmed by enzyme-linked immunosorbent assay (ELISA)] was very high in 2002 and relatively low in 2003 . Stem weight was significantly reduced in the black mulch treatment; however, plant height, leaf weight, or total numbers of flowers were not influenced by mulch type. For both years, the incidence of TSW on black mulch was significantly greater than that of the other mulch treatments for most sampling dates. The application of insecticides reduced percentage TSW on the last two sampling dates in both years. In 2002, but not 2003, yield per hectare was affected by mulch type. In both years, mulch type did not influence yield per plant and percentage marketable fruit, and insecticide applications increased yield per hectare, yield per plant, and percentage marketable fruit.
\end{abstract}

Polyethylene mulches have been used since the 1950 s to enhance vegetable crop production (Emmert, 1957). The advantages of plastic mulch include earlier crop production, increased yield per unit area, improved fruit quality, more efficient use of nutrients and water, reduced weed competition, and a potential decrease in insect and disease pests (Lamont, 1993). The influence of mulches on plant microclimate and energy balance is a function of transmittance, absorbance, and reflectance of solar radiation (Ham et al., 1993; Lamont, 2005; Tarara, 2000).

Tomato spotted wilt is caused by a virus belonging in the genus Tospovirus and the family Bunyaviridae (Adkins et al., 2009). TSW was originally described in Australia

\footnotetext{
Received for publication 31 Aug. 2011. Accepted for publication 27 Feb. 2012.

${ }^{1}$ To whom reprint requests should be addressed; e-mail pcand@ufl.edu.
}

(Brittlebank, 1919) and was first reported in the north Florida/south Georgia growing area in 1986 (Kucharek, 1986). TSWV is transmitted exclusively by thrips (Kirk, 1997). The most important thrips species in the southeastern United States are the western flower thrips (Frankliniella occidentalis Pergande) followed by the tobacco thrips (Frankliniella fusca Hinds) (Chellemi et al., 1994). Growers in northern Florida and southern Georgia have ranked TSW and thrips as their most significant disease and insect pest, respectively (Bauske, 1998). TSW is difficult to control because both the virus and the insect vectors have very broad host ranges (Roselló et al., 1996). Although there are several new tomato cultivars resistant to TSW available to producers, many still prefer to grow TSWsusceptible cultivars because of favorable horticultural traits. Management of TSW by controlling thrips with applications of broadspectrum insecticides has often failed because thrips require very little time to transmit the virus and insecticidal activity is not fast enough (Brown and Brown, 1992; Nagata et al., 2004).

Host-seeking behavior of thrips can be disrupted by incorporating ultraviolet reflectance, thereby reducing thrips numbers on and around host plants (Brown and Brown, 1992; Kirk, 1997; Kring and Schuster, 1992; Scott et al., 1989; Stavisky et al., 2002). The use of highly ultraviolet-reflective aluminized mulch as a bed covering provides this reflectance to disrupt initial flights of thrips into a field (Brown and Brown, 1992; Kring and Schuster, 1992; Scott et al., 1989). Once plants age, foliage covers the mulch so the reflectance no longer provides flight disruption (Brown and Brown, 1992; Kirk 1997). Díaz-Pérez et al. (2003) showed that vegetative top fresh weight and total fruit yield of tomato were reduced by $2.1 \%$ and $2.3 \%$, respectively, for each day before harvest that plants showed TSW symptoms.

Primary infection sites occur when thrips move from infected weed hosts that flower in early spring into tomato fields (Kirk, 1997). This early infection of young plants can produce the most severe symptoms such as stunting, leaf necrosis, and a total loss of marketable fruit (Adkins et al., 2009). Although early TSW infection may produce more symptoms, infection at any stage of plant growth may reduce yield as a result of uneven ripening and unmarketable fruit (Adkins et al., 2009; Momol et al., 2004). Primary infections can also produce a source of inoculum for secondary infections when thrips reproduce on infected plants and emerging infected adults become vectors of the virus (Momol et al., 2004; Roselló et al., 1996).

The objectives of this study were to quantify the impact of polyethylene mulch type (black, metalized, Heat stripe, and Sonoco printed) and insecticide treatment (alternating applications of spinosad and methamidophos) on the incidence of TSW, vegetative growth, yield, and fruit quality of 'FL-47' tomato (Solanum lycopersicum) in northern Florida.

\section{Materials and Methods}

Field preparation and planting. Field experiments were conducted at the North Florida Research and Education Center, Quincy, FL (Spring 2002 and 2003). Soil type was an Orangeburg loamy fine sand (Typic Paleudult: Silaceous Thermic). The soil was moldboard-plowed, double-disked, and S-tine cultivated in early March. Tomato plants were planted on raised beds. Fertilizer was applied preplant at the rate of $218 \mathrm{~N}-$ $29 \mathrm{P}-181 \mathrm{~K} \mathrm{~kg}$ per hectare. Before mulch installation, a mixture of methyl bromide (67\%)-chloropicrin $(33 \%)$ was applied at a broadcast rate of $392 \mathrm{~kg} \cdot \mathrm{ha}^{-1}$ to the bed area. Plastic mulches were all $91.4 \mathrm{~cm}$ wide and included black mulch, highly ultravioletreflective metalized mulch (Reflectek Foils, Lake Zurich, IL), Heat stripe reflective mulch (Reflectek Foils), and Sonoco printed mulch (Sonoco Products, Hartsville, SC). Metalized 
mulch was manufactured with the deposition of aluminum. Heat stripe consisted of a $20.3-\mathrm{cm}$ wide center stripe of black mulch surrounded on both sides with painted silver. Sonoco mulch was silver-painted. All mulches were $31.8 \mu \mathrm{m}$ (1.25 mil.) thick. Mulch and drip tubing were laid concurrently with fumigant application. 'FL-47' tomato (Solanum lycopersicum) plants were transplanted into the field on 27 Mar. 2002 and 31 Mar. 2003. 'FL-47' is considered to be susceptible to TSW. Irrigation was applied daily. Foliar fungicides $\left(0.44 \mathrm{~L} \cdot \mathrm{ha}^{-1}\right.$ azoxystrobin and $3.36 \mathrm{~kg} \cdot \mathrm{ha}^{-1}$ chlorothalonil) were applied alternately on a weekly basis to maintain plant health. Bacillus thuringiensis $\left(1.12 \mathrm{~kg} \cdot \mathrm{ha}^{-1}\right)$ was applied weekly to prevent Lepidopteran feeding. Plants were staked and tied.

Integration of tactics against tomato spotted wilt. A split plot experiment with five replications was conducted in the spring of 2002 and spring of 2003. Main plots were mulch type and subplots were foliar insecticide/no foliar insecticide. Each split plot consisted of two rows and a total of 80 plants. All 80 plants were scouted for TSW, although only 12 plants in the center left row were harvested for yield variables. Plots were separated from each other by $5.5 \mathrm{~m}$. Plants were spaced 0.51 and $1.83 \mathrm{~m}$ within and between rows, respectively. Insecticide treatments for thrips were a rotation of spinosad (0.07 kg a.i./ha) and methamidophos $(0.4 \mathrm{~kg}$ a.i./ha). For 2002, spinosad was applied on 25 Apr., 10 May, 24 May, and 7 June. Methamidophos was applied on 3 May, 17 May, 31 May, and 14 June. For 2003, spinosad was applied on 30 Apr., 13 May, 27 May, and 10 June. Methamidophos was applied on 6 May, 20 May, and 3 June. Henceforth, we will denote the "insecticide" treatment as the application of spinosad and methamidophos and the "no insecticide" treatment as no spinosad and methamidophos applications. Pesticides were applied using eight nozzles per row with four on each side directed into the canopy. Nozzles were type DC7-45. Pressure used was $414 \mathrm{kPa}$. Delivery volume was $841 \mathrm{~L} \cdot \mathrm{ha}^{-1}$.

Soil temperature and photosynthetic photon flux. Soil temperature was monitored beneath each mulch type at a depth of $10 \mathrm{~cm}$ midway between plants in the row center (Díaz-Pérez, 2010) with thermocouples and a Watchdog ${ }^{\mathrm{R}}$ Model 200 data logger (Spectrum Technologies, East Plainfield, IL) from 18 Apr. to 22 May 2003 (Fig. 1). Soil temperature data that were presented were collected between 1500 and 1600 HR each day. There was one thermocouple per treatment. Both incoming and reflected $P P F$ were measured on 23 May 2002 with a LICOR (LICOR, Lincoln, NE) 1600 steady-state diffusion porometer. Measurement times were 800, 1000, 1200, 1400 1600, and 1800 HR. PPF was determined on plastic mulch without (Fig. 2) and with (Fig. 3) the presence of plants. $P P F$ measurements $0.5 \mathrm{~m}$ above the ground on the four types of mulch without plants were: 1) full sunlight; and 2) reflectance perpendicular from mulch. Reflectance of the different mulches was also determined in the center of a full plant canopy. The following $P P F$ measurements taken with plants were: 1) reflectance perpendicular from mulch; 2) reflectance upward in the canopy interior at a height of $20 \mathrm{~cm}$; and 3) reflectance downward in the canopy interior at a height of $20 \mathrm{~cm}$. All measurements were replicated four times. Means \pm 1 SE were reported for measurements in full sunlight. Reflectance data were only collected from non-insecticide plots. Least significant differences were reported for all measurements of reflectance.

Plant growth variables. Plant height was recorded on 16 May 2002. There were five replications per treatment with 10 plants comprising an experimental unit. The effect of mulch on the number of flowers per plant was also determined on the same plants on 13, 20, and 29 May and on 3 and 10 June. One plant per experimental unit was harvested for leaf and stem dry weights on 16 May. Plant tissue was dried at $50{ }^{\circ} \mathrm{C}$ for 5 and $25 \mathrm{~d}$ for determination of leaf and stem dry weights, respectively. Because there was no significant insecticide effect on these variables, statistics were performed on a combined insecticide/no insecticide treatment. Mean separation was accomplished by Duncan's multiple range test $(P<0.05)$.

Disease assessment and harvest. The incidence of TSW symptomatic plants was recorded for each treatment every 10 to $15 \mathrm{~d}$. The number of plants with TSW symptoms was divided by the total number of plants at the beginning of the experiment to calculate percentage TSW. Symptomatic plants were flagged at each assessment to determine disease progress. The presence of TSWV in symptomatic plants was confirmed on 10 symptomatic plants on each sampling date through the use of ELISA (Agdia, Elkhart, IN). Thrips populations were not monitored in this study.

Tomatoes were harvested twice each season at the mature green or later stage of maturity and graded into marketable and cull categories according to U.S. Grades and Standards (<http://www.ams.usda.gov/AMSv1.0/getfile?
$\mathrm{dDocName}=$ STELPRDC5065701 $>$ ). Split plot one-way analysis of variance was used to determine effects of treatments on disease incidence (each sampling date) and yield. Mean separation tests were performed when appropriate using Duncan's multiple range test.

\section{Results and Discussion}

Plastic mulch color can greatly affect the proportion of light reflected and absorbed, thus influencing the plant microclimate, root zone temperature, and reproductive and vegetative plant growth (Ham et al., 1993; Lamont, 1993, 2005; Tarara, 2000). The following average air temperatures were recorded for 2002: 1 to $15 \mathrm{Apr}$. $=20.1^{\circ} \mathrm{C}, 16$ to $30 \mathrm{Apr}$. $23.8^{\circ} \mathrm{C}, 1$ to $15 \mathrm{May}=25.4^{\circ} \mathrm{C}, 16$ to 31 May $22{ }^{\circ} \mathrm{C}, 1$ to 15 June $=27.2^{\circ} \mathrm{C}$; and for $2003: 1$ to $15 \mathrm{Apr}$. $=17.1^{\circ} \mathrm{C}, 16$ to $30 \mathrm{Apr} .=20.3^{\circ} \mathrm{C}$, 1 to 15 May $=24.3^{\circ} \mathrm{C}, 16$ to 31 May $=23.1{ }^{\circ} \mathrm{C}$, 1 to 15 June $=24.6{ }^{\circ} \mathrm{C}$. Midafternoon soil temperature $(10 \mathrm{~cm}$ depth) generally ranged from 25 to $31{ }^{\circ} \mathrm{C}$ and was usually 2 to $4{ }^{\circ} \mathrm{C}$ higher under black mulch than the other mulch treatments (Fig. 1). These trends are consistent with previous reports of daily soil temperatures on black and reflective mulches (Csizinsky et al., 1995; Decoteau et al., 1987, 1988; DíazPérez and Batal, 2002; Ham et al., 1993; Schalk and Robbins, 1987; Tarara, 2000). Nevertheless, these temperatures were mostly within the optimum root zone temperature range $\left(26\right.$ to $34^{\circ} \mathrm{C}$ ) for the growth and mineral uptake of tomato in controlled experiments (Cooper, 1973; Gosselin and Trudel, 1983; Tindall et al., 1990). However, Díaz-Pérez and Batal (2002) reported an optimal temperature of $26{ }^{\circ} \mathrm{C}$ under field conditions. The effects of air and root zone temperature have been examined in detail (Ham et al., 1993; Tarara, 2000). A reduction in soil temperature occurred on 25 Apr. and 22 May and was the result of cloudy/rainy weather.

Incomimg and reflected $P P F$ were measured on 23 May 2002 above bare mulch (i.e., without plants) (Fig. 2) and in the presence of plant canopies (Fig. 3). $P P F$ in full sun varied from 1300 to $1800 \mu \mathrm{mol} \cdot \mathrm{m}^{-2} \cdot \mathrm{s}^{-1}$ from 800 to

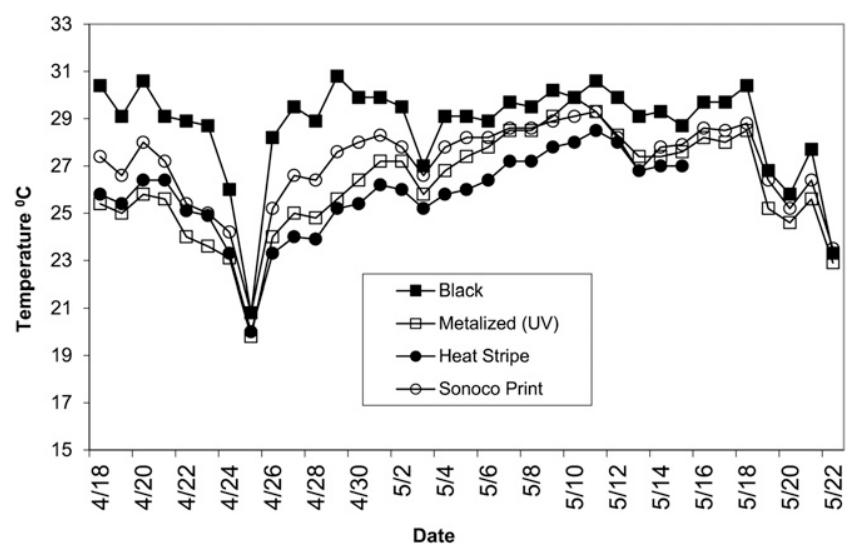

Fig. 1. Midafternoon root zone temperatures during the Spring 2003 at a depth of $10 \mathrm{~cm}$ under four mulch types. Each data point represents a single measurement. The thermocouple for the Heat stripe mulch failed on 15 to 22 May. 
1800 HR (Fig. 2). Reflectance perpendicular to mulch was highest for the metalized mulch and least for black mulch. Similar reflective properties of metalized mulch have been reported (Díaz-Pérez and Batal, 2002; DíazPérez et al., 2005; Ham et al., 1993). During midday, maximum reflectance for metalized mulch was $\approx 1000 \mu \mathrm{mol} \cdot \mathrm{m}^{-2} \cdot \mathrm{s}^{-1}$, intermediate for Heat stripe and Sonoco printed $(800$ $\left.\mu \mathrm{mol} \cdot \mathrm{m}^{-2} \cdot \mathrm{s}^{-1}\right)$, and least for black mulch (200 to $\left.400 \mu \mathrm{mol} \cdot \mathrm{m}^{-2} \cdot \mathrm{s}^{-1}\right)$. In general, reflectance was significantly less for black much than the other three mulches. On several measurement times, reflectance was greater for metalized mulch compared with Heat stripe and Sonoco printed. Díaz-Pérez (2010), working with eight plastic mulch types, showed that the percentage of $P P F$ reflected from the mulches was inversely proportional to root zone temperature. $P P F$ reflectance was substantially reduced in the presence of plant canopies (Fig. 3).

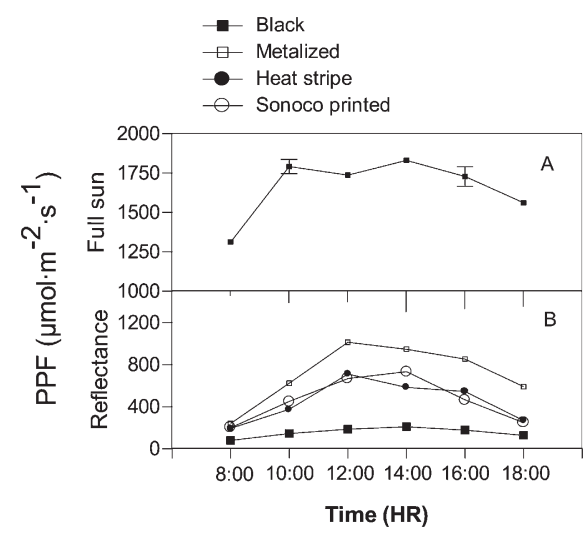

Fig. 2. (A) Diurnal photosynthetic photon flux $(P P F$ in full sun \pm 1 SEM. (B) Reflectance perpendicular to mulch of the four mulch treatments in the absence of a plant canopy. Least significant differences (LSDS) are denoted by vertical lines at top of the figure.

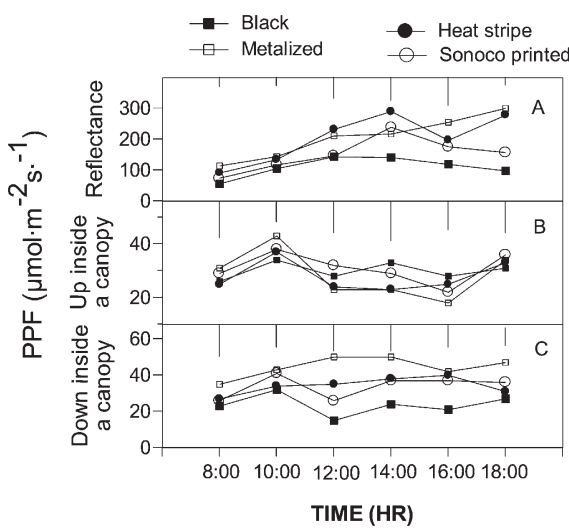

Fig. 3. The diurnal reflectance of photosynthetic photon flux $(P P F)$ of the four mulch treatments with a mature plant canopy. (A) Reflectance perpendicular to mulch, (B) incoming $P P F$ inside a canopy, and $(\mathbf{C})$ reflectance inside a canopy. Least significant differences (LSDS) are denoted by vertical lines at the top of each figure.
Reflectance in the presence of plant canopies was highest for metalized mulch and Heat stripe mulch, although significant differences did not always occur. Incoming or reflected $P P F$ inside the canopy was extremely low (20 to $40 \mu \mathrm{mol} \cdot \mathrm{m}^{-2} \cdot \mathrm{s}^{-1}$ ) for all mulch treatments. Thus, regardless of mulch type, $P P F$ inside a plant canopy was at or below the light compensation point (i.e., zero net photosynthesis) of tomato leaves (Bradford, 1984; Tartachnyk and Blanke, 2007).

Plant height and leaf weight were not significantly affected by mulch treatment, although leaf weight was $14 \%$ to $17 \%$ greater for metalized and Heat stripe mulches compared with black mulch (Table 1). Plants grown with metalized and Heat stripe mulches had significantly greater stem dry weights than the black mulch. There was a delay in flower production with the black mulch compared with other mulch treatments as evidenced by a lower flower number in the black mulch treatment on 13 May and a higher number on 10 June. Flower number was lowest for black mulch treatment on 13 May but highest on 10 June; however, the cumulative total number of flowers was unaffected by mulch type. DíazPérez et al. (2003) reported that black plastic mulch for tomato resulted in high root zone temperature, a reduced plant growth and yield, and promoted the incidence of TSW.

The incidence of plants showing TSW symptoms increased with time (Table 2). The incidence of TSW symptoms at the end of the experiments was high (average $=32.6 \%$ ) in 2002 and relatively low (average $=7.0 \%$ ) in 2003 (Table 2). Mulch type influenced TSW beginning in 17 May in 2002 and 23 May in 2003, and this effect lasted for the duration of the experiments. In both years, the black mulch had the highest incidence of TSW. The remaining mulch treatments were not

Table 1. Plant height, leaf dry weight, stem dry weight, and flower number per plant as a function of mulch types during 2002 .

\begin{tabular}{lccccccccc}
\hline & Plant & Leaf & Stem & \multicolumn{7}{c}{ Flower number } \\
\cline { 6 - 10 } Treatment & ht $(\mathrm{cm})$ & wt $(\mathrm{g})$ & wt $(\mathrm{g})$ & 13 May & 20 May & 29 May & 3 June & 10 June & Total \\
\hline Black & $83.8^{\mathrm{z}}$ & 91.2 & $78.1 \mathrm{c}$ & $17.3 \mathrm{c}$ & 22.0 & 19.2 & 16.5 & $10.4 \mathrm{a}$ & 85.4 \\
Metalized & 85.3 & 103.9 & $96.9 \mathrm{a}$ & $26.4 \mathrm{a}$ & 24.0 & 22.5 & 17.5 & $7.6 \mathrm{~b}$ & 97.9 \\
Heat stripe & 84.7 & 107.1 & $90.4 \mathrm{ab}$ & $23.1 \mathrm{~b}$ & 24.3 & 21.1 & 17.4 & $7.2 \mathrm{~b}$ & 93.1 \\
Sonoco printed & 83.2 & 96.0 & $83.2 \mathrm{bc}$ & $24.2 \mathrm{ab}$ & 23.2 & 18.4 & 16.1 & $6.9 \mathrm{~b}$ & 88.8 \\
\hline
\end{tabular}

${ }^{2}$ Means within a column followed by different letters are significantly different $P<0.05$ by Duncan's multiple range test. Variables not followed by letters are not significantly different from each other. These data represent pooled data from insecticide and non-insecticide plots because there were no significantly treatment differences.

Table 2. Effect of mulch types and insecticide treatment on the incidence (\%) of plant showing tomato spotted wilt (TSW) symptoms in 2002 and 2003.

\begin{tabular}{|c|c|c|c|c|c|c|}
\hline \multicolumn{7}{|c|}{2002} \\
\hline \multicolumn{7}{|c|}{ Incidence of TSW (\%) } \\
\hline Treatment & 25 Apr. & 7 May & 17 May & 29 May & 10 June & 20 June \\
\hline \multicolumn{7}{|l|}{ Mulch } \\
\hline Black & $0.7^{\mathrm{z}}$ & 4.0 & $14.9 \mathrm{a}^{\mathrm{z}}$ & $28.1 \mathrm{a}$ & $38.6 \mathrm{a}$ & $46.6 \mathrm{a}$ \\
\hline Metalized & 1.0 & 2.8 & $6.7 \mathrm{~b}$ & $13.5 \mathrm{~b}$ & $20.2 \mathrm{~b}$ & $25.1 \mathrm{c}$ \\
\hline Heat stripe & 0.8 & 3.0 & $6.7 \mathrm{~b}$ & $13.9 \mathrm{~b}$ & $18.6 \mathrm{~b}$ & $23.5 \mathrm{c}$ \\
\hline Sonoco printed & 1.2 & 3.7 & $9.5 \mathrm{~b}$ & $20.0 \mathrm{~b}$ & $26.7 \mathrm{~b}$ & $35.0 \mathrm{~b}$ \\
\hline \multicolumn{7}{|l|}{ Insecticide } \\
\hline Insecticide & 0.7 & $2.9 \mathrm{~b}$ & 8.4 & 16.7 & $20.6 \mathrm{~b}$ & $24.9 \mathrm{~b}$ \\
\hline No insecticide & 1.2 & $3.8 \mathrm{a}$ & 10.5 & 21.0 & $31.5 \mathrm{a}$ & $40.2 \mathrm{a}$ \\
\hline \multicolumn{7}{|l|}{ Significance } \\
\hline Mulch & $\mathrm{NS}^{\mathrm{y}}$ & NS & $* * *$ & ** & $* *$ & $* * *$ \\
\hline Insecticide & NS & $*$ & NS & NS & $* * * *$ & $* * * *$ \\
\hline \multicolumn{6}{|c|}{2003} & NS \\
\hline \multicolumn{7}{|c|}{ Incidence of TSW (\%) } \\
\hline Treatment & 15 May & 23 May & 29 May & 6 June & 12 June & \\
\hline \multicolumn{7}{|l|}{ Mulch } \\
\hline Black & $2.6^{z}$ & $6.6 \mathrm{a}$ & $9.2 \mathrm{a}$ & $13.3 \mathrm{a}$ & $13.6 \mathrm{a}$ & \\
\hline Metalized & 0.5 & $1.3 \mathrm{~b}$ & $1.8 \mathrm{~b}$ & $2.7 \mathrm{~b}$ & $2.7 \mathrm{~b}$ & \\
\hline Heat stripe & 1.0 & $2.2 \mathrm{~b}$ & $3.0 \mathrm{~b}$ & $5.3 \mathrm{~b}$ & $5.5 \mathrm{~b}$ & \\
\hline Sonoco printed & 1.3 & $2.5 \mathrm{~b}$ & $4.2 \mathrm{~b}$ & $5.7 \mathrm{~b}$ & $6.3 \mathrm{~b}$ & \\
\hline \multicolumn{7}{|l|}{ Insecticide } \\
\hline Insecticide & 1.5 & 2.9 & 4.04 & $5.6 \mathrm{~b}$ & $5.9 \mathrm{~b}$ & \\
\hline No insecticide & 1.2 & 3.4 & 5.03 & $7.8 \mathrm{a}$ & $8.2 \mathrm{a}$ & \\
\hline \multicolumn{7}{|l|}{ Significance } \\
\hline Mulch & $\mathrm{NS}^{\mathrm{y}}$ & * & $* *$ & $* * *$ & $* * *$ & \\
\hline Insecticide & NS & NS & NS & $*$ & * & \\
\hline Mulch*insecticide & NS & NS & NS & $*$ & NS & \\
\hline
\end{tabular}

"Means within a column followed by different letters are significantly different $P<0.05$ by Duncan's multiple range test. Variables not followed by letters are not significantly different from each other. ${ }_{\mathrm{NS}}, *, * *, * * *$, and $* * * *$ represent, nonsignificant, significant at $0.05,0.01,0.001$, and 0.0001 , respectively, for each treatment or interaction between treatments. 
significantly different from one another except for the final assessment on 20 June 2002 when metalized and Heat stripe mulch had the lowest incidence of TSW. At the end of the experiments, the metalized and Heat stripe mulches reduced the incidence of TSW from $24 \%$ to $47 \%$ in 2002 and $54 \%$ to $80 \%$ in 2003 compared with black mulch.

Numerous studies have shown that thrips are repelled and the incidence of TSW is reduced by metalized mulches (Brown and Brown, 1992; Díaz-Pérez et al., 2003; Kirk, 1997; Kring and Schuster, 1992; Momol et al., 2004; Nagata et al., 2004, Olson et al., 2000; Orzolek et al., 2000; Scott et al., 1989; Stavisky et al., 2002). Stavisky et al. (2002) reported that reflective mulches and lower rates of nitrogen fertilization reduced thrips populations and the consequent incidence of TSW. Moreover, reflective mulches, when combined with an intensive insecticide treatment, have also reduced the number of thrips and TSW (Momol et al., 2004; Riley and Pappu, 2000; Stavisky et al., 2002). In general, mulch type had a more significant effect on the incidence of TSW than insecticide applications early in the season. Insecticide applications reduced the incidence of TSW, particularly during the last two measurement dates. By the last two sampling dates in each year, both mulch type and insecticide influenced TSW. At the end of sampling, the insecticide treatment reduced the incidence of TSW by $38 \%$ and $28 \%$ in 2002 and 2003, respectively, compared with the non-insecticide treatment.
There was only one mulch $\times$ insecticide interaction (6 June 2003).

In 2002, a year with high TSW (average final TSW $=32.6 \%$ ), yield per hectare, but not yield per plant was influenced by mulch treatment (Table 3). This was because TSWinfected plants did not produce fruit; yield from the remaining plants unaffected by TSW (kg/plant) was not significantly influenced by mulch treatment. Yield (MT $h^{-1}$ ) was higher on metalized mulch than black mulch. There were no differences among black, Heat stripe, and Sonoco printed mulches. There was no mulch effect on yield per plant, fruit weight, or percent marketable fruit. By contrast, the insecticide treatment increased yield per hectare, yield per plant, and the percent marketable fruit. Insecticide effect was significant on 7 May and again on 10 and 20 June. There were no mulch $\times$ insecticide interactions.

In 2003, a year with low TSW incidence (average final TSW $=7.0 \%$ ), mulch type did not influence yield per hectare, yield per plant, or the percent marketable fruit (Table 2). Although mulch-induced changes in plant microclimate can also impact vegetative and reproductive growth (Ham et al., 1993; Lamont, 2005; Tarara, 2000), the low incidence of TSW in 2003 may have reduced the probability of a significant mulch effect. By contrast, insecticide applications increased yield per hectare, yield per plant, and the percent of marketable fruit. Fruit weights were highest for the black and Sonoco printed

Table 3. Effect of mulch types and insecticide treatment on yield/ha, yield/plant, fruit weight, and percent marketable fruit of 'FL 47' tomatoes in 2002 and 2003.

\begin{tabular}{|c|c|c|c|c|}
\hline \multicolumn{5}{|c|}{2002} \\
\hline Treatment & Yield (MT'ha $\left.{ }^{-1}\right)$ & Yield (kg/plant) & Fruit wt $(\mathrm{g})$ & Marketable fruit (\%) \\
\hline \multicolumn{5}{|l|}{ Mulch } \\
\hline Black & $27.8 b^{z}$ & 4.87 & 189 & 88 \\
\hline Metalized & $47.0 \mathrm{a}$ & 5.83 & 186 & 90 \\
\hline Heat stripe & $44.9 \mathrm{ab}$ & 5.48 & 180 & 88 \\
\hline Sonoco printed & $37.8 \mathrm{~b}$ & 5.37 & 189 & 88 \\
\hline \multicolumn{5}{|l|}{ Insecticide } \\
\hline Insecticide & $46.6 \mathrm{a}$ & $5.79 \mathrm{a}$ & 189 & $90 \mathrm{a}$ \\
\hline No insecticide & $32.2 \mathrm{~b}$ & $4.90 \mathrm{~b}$ & 183 & $87 \mathrm{~b}$ \\
\hline \multicolumn{5}{|l|}{ Significance } \\
\hline Mulch & $* y$ & NS & NS & NS \\
\hline Insecticide & $* * *$ & $* * * *$ & NS & $* *$ \\
\hline Mulch*insecticide & NS & NS & NS & NS \\
\hline \multicolumn{5}{|c|}{2003} \\
\hline Treatment & Yield (MT.ha' ${ }^{-1}$ ) & Yield (kg/plant) & Fruit wt (g) & Marketable fruit (\%) \\
\hline \multicolumn{5}{|l|}{ Mulch } \\
\hline Black & $47.5^{\mathrm{z}}$ & 5.07 & $192 \mathrm{a}$ & 89 \\
\hline Metalized & 52.4 & 5.01 & $164 \mathrm{c}$ & 84 \\
\hline Heat stripe & 52.8 & 5.20 & $180 \mathrm{~b}$ & 87 \\
\hline Sonoco printed & 54.9 & 5.43 & $194 \mathrm{a}$ & 89 \\
\hline \multicolumn{5}{|l|}{ Insecticide } \\
\hline Insecticide & $55.8 \mathrm{a}$ & $5.48 \mathrm{a}$ & 185 & $89 \mathrm{a}$ \\
\hline No insecticide & $48.1 \mathrm{~b}$ & $4.86 \mathrm{~b}$ & 180 & $86 \mathrm{~b}$ \\
\hline \multicolumn{5}{|l|}{ Significance } \\
\hline Mulch & $\mathrm{NS}^{\mathrm{y}}$ & NS & $* * * *$ & NS \\
\hline Insecticide & $*$ & $*$ & NS & * \\
\hline Mulch*insecticide & NS & NS & NS & NS \\
\hline
\end{tabular}

${ }^{\mathrm{z}}$ Means within a column followed by different letters are significantly different $P<0.05$ by Duncan's multiple range test. Variables not followed by letters are not significantly different from each other.

${ }^{\mathrm{N}_{\mathrm{NS}}, * \text {, and }}{ }^{* * *}$ represent, nonsignificant, significant at 0.05 and 0.0001 , respectively, for each treatment or interaction between treatments.

mulches and the reason for this is not clear. There were no mulch*insecticide interactions.

Reflective mulches are effective at reducing incidence of TSW in the early portions of the season when plants are small and adequate ultraviolet light is reflected from the mulch surface (Brown and Brown, 1992; Ham et al., 1993; Hatt Graham et al., 1995). Reflective mulches can reduce the number of thrips and the incidence of TSW compared with black mulch by reducing primary infection from outside the tomato field (Momol et al., 2004; Olson et al., 2000; Riley and Pappu, 2000; Stavisky et al., 2002). Once plants grow and begin to shade the bed surface, less light is reflected (Brown and Brown, 1992; Ham et al., 1993; Hatt Graham et al., 1995) and thus less thrips are repelled; at this time insecticides play an important role in TSW management (Momol et al., 2004; Olson et al., 2000; Riley and Pappu, 2000; Stavisky et al., 2002). Once infections occur, it is important to use insecticides to control the secondary spread of the disease from plant to plant in the tomato field (Momol et al., 2004; Olson et al., 2000; Riley and Pappu, 2000; Stavisky et al., 2002). We propose that this is why the insecticide treatment reduced TSW late in the season and why insecticide treatment increased yield in 2002 and 2003.

In conclusion, midafternoon soil temperature at the $10-\mathrm{cm}$ depth ranged from 25 to $31{ }^{\circ} \mathrm{C}$ and was usually $\approx 2$ to $4{ }^{\circ} \mathrm{C}$ higher under black mulch compared with the three reflective mulches. During midday in the absence of a plant canopy, $P P F$ reflectance was $\approx 60 \%, 40 \%, 40 \%$, and $10 \%$ of full sunlight $P P F$ for the metalized, Heat stripe, Sonoco printed, and black mulch, respectively. Reflectance was greatly reduced in the presence of a plant canopy under all circumstances. The only vegetative growth variable that was affected by mulch treatment was stem dry weight (reduced in the black mulch treatment). Early-season flower numbers were lowest for the black mulch, highest for the metalized much, and intermediate for Heat stripe and Sonoco printed mulch. The use of reflective plastic mulch reduced the incidence of TSW compared with black mulch both in 2002 (a year of high TSW incidence) and 2003 (a year of relatively low TSW incidence). In both years, the application of insecticides significantly reduced the incidence of TSW only during the late season. Metalized mulch increased yield/ha in 2002 but not 2003 . Insecticide treatment increased yield per hectare, yield per plant, and percent marketable fruit in both 2002 and 2003. This study illustrates the benefit of reflective mulches over black mulch and the applications of insecticides for the management of TSW for the production of spring crops of tomatoes in north Florida.

\section{Literature Cited}

Adkins, S., T. Zitter, and T. Momol. 2009. Tospoviruses (family Bunyaviridae, genus Tospovi$r u s$ ). University of Florida, EDIS publ. PP212. $<$ http://edis.ifas.ufl.edu $>$. 
Bauske, E.M. 1998. Southeastern tomato growers adopt integrated pest management. HortTechnology 8:40-44.

Bradford, K.J. 1984. Effects of flooding on leaf gas exchange of tomato leaves. Plant Physiol. 73:475-479.

Brittlebank, C.C. 1919. Tomato diseases. J. Agr. Victoria 17:231-235.

Brown, S.L. and J.E. Brown. 1992. Effect of plastic mulch color and insecticide on thrips population and damage to tomato. HortTechnology 2:208-210.

Chellemi, D.O., J.E. Funderburk, and D.W. Hall. 1994. Seasonal abundance of flower-inhabiting Frankliniella species (Thysanoptera:Thripidae) on wild plant species. Environ. Entomol. 23: 337-342.

Cooper, A.J. 1973. Root temperature and plant growth-A review. Commonwealth Agr. Bureaux, Slough, UK.

Csizinsky, A.A., D.J. Schuster, and J.B. Kring. 1995. Color mulches influence yield and insect pest populations in tomatoes. J. Amer. Soc. Hort. Sci. 120:778-784.

Decoteau, D.R., M.J. Kasperbauer, D.D. Daniels, and P.G. Hunt. 1987. The influence of plastic mulch color on the plant light environment and tomato seedling development. HortScience 22:123.

Decoteau, D.R., M.J. Kasperbauer, D.D. Daniels, and P.G. Hunt. 1988. Plastic mulch color effects on reflective light and tomato plant growth. Sci. Hort. 34:169-175.

Díaz-Pérez, J.C. 2010. Bell pepper (Capsicum annum L.) grown on plastic film mulches: Effects on crop microenvironment, physiological attributes and fruit yield. HortScience 45:1196-1204.

Díaz-Pérez, J.C. and K.D. Batal. 2002. Colored plastic film mulches affect tomato growth and yield via root zone temperature. J. Amer. Soc. Hort. Sci. 127:127-136.

Díaz-Pérez, J.C., K.D. Batal, D. Granberry, D. Bertrand, and D. Giddings. 2003. Growth and yield of tomato on plastic film mulches as affected by tomato spotted wilt virus. HortScience 38:395-399.

Díaz-Pérez, J.C., S.C. Phatak, D. Giddings, B. Bertrand, and H.A. Mills. 2005. Root zone temperature, plant growth and fruit yield of tomatillo as affected by plastic film mulch. HortScience 40:1312-1319.

Emmert, E.M. 1957. Black polyethylene for mulching vegetables. Proc. Amer. Soc. Hort. Sci. 69:464-469.

Gosselin, A. and M.J. Trudel. 1983. Interactions between air and root temperatures on greenhouse tomato: I. Growth, development and yield. J. Amer. Soc. Hort. Sci. 108:901-905.

Ham, J.M., G.T. Kluitenberg, and W.J. Lamont. 1993. Optical properties of plastic mulches affect the field temperature regime. J. Amer. Soc. Hort. Sci. 118:188-193.

Hatt Graham, H.A., D.R. Decoteau, and D.E. Linvill. 1995. Development of a polyethylene mulch that changes color in the field. HortScience 30:265-269.

Kirk, W.D.J. 1997. Distribution, abundance, and population dynamics, p. 217-257. In: Lewis, T. (ed.). Thrips as crop P. CAB International, Wallingford, UK.

Kring, J.B. and D.J. Schuster. 1992. Management of insects on pepper and tomato with UVreflective mulches. Fla. Entomol. 85:9-14.

Kucharek, T. 1986. Proceedings of the Florida Tomato Institute, Vegetable Crops Extension Report VEC 86-1. University of Florida, Gainesville, FL.

Lamont, W.J. 1993. Plastic mulches for the production of vegetable crops. HortTechnology 3:35-39.

Lamont, W.J. 2005. Plastics: Modifying the microclimate for the production of vegetable crops. HortTechnology 15:477-481.

Momol, M.T., S.M. Olson, J.E. Funderburk, and J. Stavisky. 2004. Integrated management of tomato spotted wilt on field-grown tomatoes. Plant Dis. 88:882-890.

Nagata, T., A.C.L. Almeida, R.O. Resende, and A.C. DeAvila. 2004. The competence of four thrips species to transmit and replicate four tospoviruses. Plant Pathol. 53:136-140.

Olson, S.M., J. Stavisky, T. Momol, and J. Funderburk. 2000. Relative mulches and their effect on tomato yield and insect and disease management. Proc. Natl. Agr. Plastics Congr. 29:605-609.

Orzolek, M.D., L. Otjen, and J.E. Fleck. 2000. Update: Effect of colored mulches on pepper and tomato production. Proc. Natl. Agr. Plastics Congr. 29:321-329.

Riley, D.G. and H.R. Pappu. 2000. Evaluation of tactics for management of thrips-vectored tomato spotted wilt virus in tomato. Plant Dis. 84:847-852.

Roselló, S., M.J. Díez, A. Lacasa, C. Jord'a, and F. Nuez. 1996. Viral diseases causing the greatest economic losses to the tomato crop. I. The tomato spotted wilt virus (TSWV) - A review. Sci. Hort. 67:117-150.

Schalk, J.M. and M.L. Robbins. 1987. Reflective mulches influence plant survival, production, and insect control in fall tomatoes. HortScience 22:30-32.

Scott, S.J., P.J. McLeod, F.W. Montgomery, and C.A. Handler. 1989. Influence of reflective mulch on incidence of thrips (Thysanoptera: Thripidae:Phlaeothripidae) in staked tomatoes. J. Entomol. Sci. 24:422-427.

Stavisky, J., J.E. Funderburk, B.V. Brodbeck, S.M. Olson, and P.C. Andersen. 2002. Population dynamics of Frankliniella spp. and tomato spotted wilt incidence as influenced by cultural management in tomato. J. Econ. Entomol. 95:1216-1221.

Tarara, J.M. 2000. Microclimate modifications of plastic mulch. HortScience 35:169-180.

Tartachnyk, I.I. and M.M. Blanke. 2007. Photosynthesis and transpiration of tomato and $\mathrm{CO}_{2}$ fluxes in a greenhouse under changing environmental conditions. Ann. Appl. Biol. 150:149-156.

Tindall, J.A., H.A. Mills, and D.E. Radcliffe. 1990. The effect of root zone temperature on nutrient uptake of tomato. J. Plant Nutr. 13:939-956. 